Jurnal Agro 7(2), 2020

\title{
STABILITAS DAN ADAPTABILITAS DAYA HASIL HIBRIDA JAGUNG MANIS PADJADJARAN BERDASARKAN ANALISIS AMMI
}

\section{STABILITY AND ADAPTABILITY OF PADJADJARAN SWEETCORN BASED ON AMMI}

\author{
Dedi Ruswandi ${ }^{1}$, Edy Suryadi ${ }^{2}$, Muhammad Syafii ${ }^{3}$, Anne Nuraini ${ }^{1}$, Yuyun Yuwariah ${ }^{1}$ \\ ${ }^{1}$ Fakultas Pertanian, Universitas Padjadjaran \\ ${ }^{2}$ Fakultas Teknologi Industri Pertanian, Universitas Padjadjaran \\ Jl. Raya Bandung Sumedang KM.21, Hegarmanah, Kec. Jatinangor, Kabupaten Sumedang, Jawa \\ Barat 45363 \\ ${ }^{3}$ Fakultas Pertanian, Universitas Singaperbangsa \\ Pasirjengkol, Kec. Majalaya, Kabupaten Karawang, Jawa Barat 41371 \\ *Korespondensi : d.ruswandi@unpad.ac.id
}

Diterima : 7 April 2020 / Disetujui : 28 November 2020

\begin{abstract}
ABSTRAK
Evaluasi interaksi G x E melalui pengujian multilokasi merupakan tahapan penting untuk menentukan stabilitas dan adaptabilitas hibrida superior. Untuk menentukan interaksi $\mathrm{G} \times \mathrm{E}$, stabilitas dan adaptabilitas hibrida jagung manis Padjadjaran di Jawa Barat, enam belas hibrida Padjadjaran dan dua hibrida komersial diuji di tiga lokasi selama dua musim yang berbeda di Jawa Barat- Indonesia. Hasil memperlihatkan bahwa biplot AMMI dapat dengan akurat menentukan interaksi $G \times$ E, stabilitas, dan adapatabilitas hasil hibrida jagung manis Padjadjaran di Jawa Barat. Biplot AMMI mengidentifikasi bahwa hibrida jagung manis Padjadjaran G 10 sebagai jagung manis yang stabil di berbagai lokasi pengujian dan musim di Jawa Barat, sedangkan hibrida jagung manis Padjadjaran G5 dan Padjadjaran G11 sebagai hibrida yang spesifik lingkungan. Biplot AMMI disarankan sebagai alat menentukan hibrida superior yang akan dilepas di Indonesia.
\end{abstract}

Kata kunci: adaptabilitas, AMMI, interaksi G x E, jagung Manis, stabilitas

\begin{abstract}
Evaluation of genotype $(G) x$ environment $(E)$ interaction through multi-location testing is an important phase to determined stability and adaptability of superior hybrid. To determined $\mathrm{G} x$ $E$ interaction, stability and adaptability of Padjadjaran sweet corn hybrids, sixteen new Padjadjaran sweetcorn hybrids and two commercial hybrids were tested in three locations for two different seasons in West Java, Indonesia. Results showed that AMMI biplot was accurately determined G x E interaction, stability and adaptability of Indonesian sweet corn in West Java for yield. The AMMI biplot determined Padjadjaran G 10 sweetcorn hybrid as a stable hybrid across locations and seasons in West Java, while Padjadjaran G5 and G11 as the specific environment hybrid. The AMMI biplot is suggested to implement as a tool to release particular superior hybrid in Indonesia.
\end{abstract}

Key words : adaptability, AMMI, G x E interaction, sweetcorn, stabilit

Cite this as: Ruswandi, D., Suryadi, E., Syafii, M., Nuraini, A. \& Yuwariah, Y. (2020). Stabilitas dan adaptabilitas daya hasil hibrida jagung manis padjadjaran berdasarkan analisis AMMI. Jurnal Agro, 7(2), 169-178. https://doi.org/10.15575/8153 


\section{PENDAHULUAN}

Jagung manis merupakan sayuran penting yang memiliki kandungan nutrisi lengkap seperti karbohidrat, protein, vitamin, dan beragam mineral penting lainnya. Kebutuhan jagung manis di Indonesia semakin meningkat dari tahun ke tahun, namun produksi dan produktivitasnya belum optimal. Beberapa faktor pembatas antara lain variasi agroekosistem di Indonesia yang tinggi dan pemanfaatan kultivar hibrida yang rendah. Produksi dan produktifitas jagung manis dapat ditingkatkan dengan budidaya varietas hibrida jagung manis berdaya hasil tinggi, peningkatan produktifitas lahan, dan rotasi kultivar hibrida jagung manis berdaya hasil tinggi dan adaptif terhadap lokasi dan musim tanam (Ruswandi et al., 2016). Kunci sukses strategi ini ditentukan oleh varietas hibrida jagung manis berdaya hasil tinggi dan adaptif terhadap pola tanam dan musim tertentu yang terpilih melalui seleksi.

Tahapan penting seleksi hibrida unggul adalah pengujian multilokasi. Pengujian multilokasi dilakukan untuk mengkaji interaksi hibrida $x$ lingkungan dan menyeleksi hibrida stabil pada berbagai lingkungan atau beradaptasi pada lingkungan spesifik (Balestre et al., 2009). Pengujian tanaman pada berbagai kondisi lingkungan menyebabkan penampilan suatu genotip tidak sama pada lokasi dan musim yang berbeda (Fan et al., 2007). Variasi yang muncul pada penampilan genotip tersebut disebabkan oleh efek interaksi genotip $\times$ lingkungan ( $\mathrm{G} \times \mathrm{E}$ ) (Brown \& Caligari, 2008). Seleksi genotip untuk memaksimalkan hasil ketika ranking genotip berubah pada lingkungan berbeda sangat rumit karena kompleksitas respon genotip. Identifikasi faktor penyebab interaksi $G \times E$ penting dalam menentukan tujuan pemuliaan, kondisi ideal pengujian dan menentukan varietas regional yang memiliki adaptasi yang baik.

Beberapa metode statistik yang dapat digunakan dalam menentukan stabilitas dan adaptibilitas varietas antara lain: metode analisis varians, analisis regresi linier/non linier, analisis multivariat, non-parametrik dan biplot. Analisis AMMI (Additive main effects and multiplicative interaction model) adalah metode statistik multivariat yang digunakan untuk mengkaji interaksi $\mathrm{G} \times \mathrm{E}$ berdasarkan biplot. Analisis ini digunakan untuk menganalisis stabilitas dan interaksi $\mathrm{G}$ $x$ E pada berbagai komoditi penting pertanian seperti: sorgum manis (Aruna et al., 2015), terigu (Castillo et al., 2012), markisa (Oliveira et al., 2014), jagung (BaduApraku et al., 2015), kacang faba (Flores et al., 2013; Temesgen et al., 2015), padi (Akter et al., 2015)), kentang (Rak et al., 2013), kacang merah (Hoyos-Villegas et al., 2016) dan bunga matahari (van der Merwe et al., 2013). Pada jagung, AMMI biplot sangat efektif digunakan untuk mengevaluasi jagung yang stabil dan adaptif pada berbagai lingkungan stress biotik maupun abiotik. Badu-Apraku et al. (2012); Badu-Apraku et al. (2016) berhasil menyeleksi jagung berdaya hasil tinggi yang toleran terhadap kekeringan dan cekaman Nitrogen serta jagung putih berdaya hasil tinggi yang stabil pada berbagai lingkungan multi cekaman berdasarkan metode AMMI.

AMMI biplot memiliki keunggulan antara lain: dapat menerjemahkah efek genotip dan lingkungan sebagai aditif dan interaksi $G \times E$ sebagai multiplikatif dengan teknik analisis komponen utama (principal component analysis); memiliki kemampuan mendekomposisi keragaman pengaruh interaksi dan bersifat fleksibel dalam 
menangani model suatu gugus data, tetapi memiliki keakuratan pendugaan nilai responsnya yang relatif sama dengan model regresi; mampu memilah-milah pengaruh interaksi atas komponen-komponen utama yang bersifat orthogonal, analisis dilakukan secara serempak dengan menggunakan genotipe dan lingkungan sekaligus, dan bukan secara parsial antara genotipe pada setiap lingkungan dengan indeks lingkungan seperti pada model regresi (Gauch \& Zobel, 1996). Adapun tujuan studi ini adalah untuk mempelajari interaksi G x E dan menentukan stabilitas dan adaptabilitas hasil jagung manis Padjadjaran di lokasi dan musim yang berbeda di Jawa Barat berdasarkan metode AMMI.

\section{BAHAN DAN METODE}

Percobaan dilaksanakan selama awal musim penghujan selama dua tahun berturut- turut yaitu tahun 1 (Maret sampai Juli, 2014) dan tahun 2 (Maret sampai Juli, 2015). Adapun tiga lokasi di Jawa Barat tersebut adalah: Jatinangor - Sumedang, Lembang - Kabupaten Bandung Barat, dan Wanayasa - Kabupaten Purwakarta.

Pada penelitian ini digunakan enam belas hibrida sweet corn SR Padjadjaran dan dua kultivar cek. Hibrida tersebut ditanam di tiga lokasi selama dua musim berdasarkan rancangan tata ruang Rancangan acak kelompok diulang tiga kali. Materi genetik yang digunakan adalah: G1 (BS= Bisi sweet), G2 (SB= Sweet Boy), Padjadjaran G3 (15 x 17), Padjadjaran G4 (22 x 17), Padjadjaran $G 5$ (24 x 17), Padjadjaran G6 (25 x 17), Padjadjaran G7 (26 x 17), Padjadjaran G8 (30 x 17), Padjadjaran G9 (31 x 17), Padjadjaran G9 (31 x 17), Padjadjaran G10 (32 x 17), Padjadjaran G11 (33 x 17), Padjadjaran G12 (4 $x$ 17), Padjadjaran G13 (41 x 17),
Padjadjaran G14 (43 x 17), Padjadjaran G15 (46 x 17), Padjadjaran G16 (47 x 17), Padjadjaran G17 (52 x 17), dan Padjadjaran G18 (9 x 17).

Model linier untuk setiap lokasi pengujian adalah mengikuti (Gomez \& Gomez, 1995). Pengujian $F$ pada analisis varians tunggal dilakukan untuk menunjukkan perbedaan nyata variasi daya hasil yang diamati pada setiap lokasi. Analisis gabungan untuk mengidentifikasi interaksi $G \times E$ mengikuti model analisis berdasarkan model linier yang dideskripsikan oleh Gomez \& Gomez (1995).

Informasi stabilitas dan adaptabilitas hibrida menggunakan metode AMMI (Additive Main Effect and Multiplicative Interaction). Persamaan Fix Model AMMI mengikuti (Gauch \& Zobel, 1996):

$Y_{\text {ger }}=\mu+\alpha_{g}+\beta_{e}+\sum_{n} \lambda_{n} \gamma_{g n} \delta_{e n}+\rho_{g e}+\varepsilon_{\text {ger }}$ Di mana :

$\mu .=$ Rata-rata umum,

$\alpha_{\mathrm{g}}=$ deviasi genotip g dari rata-rata umum,

$\beta_{\mathrm{e}}=$ deviasi dari lingkungan $\mathrm{e}$,

$\lambda_{n}=$ nilai tunggal IPCA (Interaction Principal Component Axis),

$\mathrm{V}_{\mathrm{gn}}=$ eigenvector genotip untuk axis $\mathrm{n}$,

$\delta_{\mathrm{en}}=$ eigenvector lingkungan,

$\rho_{\mathrm{ge}}=$ residual

$\varepsilon_{\text {ger }}=$ error

Jika komponen IPCA yang bermakna adalah IPCA-1, maka model yang berlaku adalah AMMI-1. Tetapi bila komponen IPCA1 dan IPCA-2 bermakna, maka model yang berlaku adalah AMMI-2. Interpretasi hasil analisis AMMI didasarkan pada grafik biplot yang dikontruksi dari nilai rata-rata dan nilai skor IPCA atau antar nilai skor IPCA. Analisis varians gabungan, analisis model dan biplot AMMI dilakukan dengan bantuan perangkat lunak Statistic for Agriculture Research (STAR) dan Plant Breeding (PB) Tools yang dikembangkan oleh IRRI (2014a, 2014b). 


\section{HASIL DAN PEMBAHASAN}

Berdasarkan analisis gabungan diketahui adanya interaksi G x E yang nyata untuk karakter hasil (Tabel 1). Interaksi tersebut mencakup interaksi genotip dengan musim dan lokasi.

Tabel 1. Analisis varian hasil hibrida jagung manis Padjadjaran di Jawa Barat

\begin{tabular}{lrrrr}
\hline $\begin{array}{l}\text { Sumber } \\
\text { Variasi }\end{array}$ & DB & JK & KT & $F_{\text {hitung }}$ \\
\hline Total & 324 & 3782,33 & 11,71 & \\
Perlakuan & 107 & 2662,16 & 24,88 & $6,60 * *$ \\
G & 17 & 199,24 & 11,72 & $3,11^{* *}$ \\
E & 5 & 1626,40 & 325,28 & $11,12^{* *}$ \\
Blok & 12 & 351,12 & 29,26 & $7,75^{* *}$ \\
Gx E & 85 & 837,25 & 9,85 & $2,61^{* *}$ \\
Eror & 204 & 770,00 & 3,77 & \\
\hline$* *, *$ & & & & \\
\end{tabular}

tingkat kemungkinan 0.01 dan 0.05, dan tidak berbeda nyata; $\mathrm{DB}=$ derajat bebas; JK= Jumlah Kuadrat; $\mathrm{KT}=$ Kuadrat tengah; $\mathrm{E}=$ Lingkungan; $\mathrm{G}$ $=$ Hibrida; $\mathrm{G} \times \mathrm{E}=$ Hibrida $\times$ Lingkungan

Hasil merupakan karakter yang sangat penting pada saat melakukan evaluasi tanaman. Terdapat variabilitas yang sangat besar pada ekspresi karakter- karakter yang berasosiasi dengan hasil pada lingkungan yang berbeda yang merupakan efek lingkungan pada karakter-karakter tersebut (Castillo et al., 2012). Hasil merupakan karakter yang kompleks yang merupakan interaksi antara serangkaian kombinasi proses biokimia dengan banyak gen dan faktor genetik dan lingkungan seperti karaktersistik tanah, curah hujan, kesuburan tanah, temperature tanah dan udara, serta interaksi G x E (Castillo et al., 2012)

Interaksi genotip dengan lingkungan yang nyata pada karakter hasil ditampilkan pada Tabel 1 yang dilanjutkan dengan analisis AMMI pada Tabel 2. Berdasarkan hasil Tabel 2 terungkap persentase akumulasi nilai Jumlah Kuadrat IPCA-1 dan IPCA-2 yang berbeda nyata untuk hasil, berturut- turut dengan nilai akumulasi $51,4 \%$ dan $81,7 \%$. Adapun data hasil ditampilkan pada Tabel 3.

Interaksi G x E disebabkan adanya pengaruh faktor lingkungan yang berbeda. Faktor lingkungan sebagai komponen utama interaksi bisa berupa faktor lokasi, faktor musim ataupun interaksi antar faktor lokasi dengan musim. Faktor tersebut mengakibatkan daya hasil yang berbeda pada setiap lingkungan tumbuh.

Tabel 2. Analisis AMMI untuk hasil hibrida jagung manis Padjadjaran di Jawa Barat

\begin{tabular}{crrrrrl}
\hline Sumber Variasi & \multicolumn{1}{c}{$\%$} & Akumulasi & DB & \multicolumn{1}{l}{ JK } & \multicolumn{1}{c}{ KT } & F Fitung \\
\hline PC1 & 51,41 & 51,41 & 21 & 430,26 & 20,49 & $5,43^{* *}$ \\
PC2 & 30,26 & 81,68 & 19 & 253,28 & 13,33 & $3,53^{* *}$ \\
PC3 & 10,53 & 92,21 & 17 & 88,14 & 5,18 & $1,37^{*}$ \\
PC4 & 4,09 & 96,29 & 15 & 34,19 & 2,28 & 0,60 \\
PC5 & 3,71 & 100,00 & 13 & 31,03 & 2,39 & 0,63 \\
\hline
\end{tabular}

**, * dan $^{\mathrm{ns}}$ berbeda nyata berturut- turut pada tingkat kemungkinan 0.01 dan 0.05 , dan tidak berbeda nyata; $\mathrm{DB}=$ derajat bebas; $\mathrm{JK}=\mathrm{Jumlah}$ Kuadrat; $\mathrm{KT}=$ Kuadrat tengah;

Hal ini menunjukkan bahwa hibridahibrida yang diuji memiliki respon yang berbeda pada ke-enam lingkungan tumbuh dan berdasarkan karakter tersebut dapat dikembangkan kultivar hibrida jagung manis berdaya hasil tinggi yang spesifik lokasi/ musim. Studi yang dilakukan beberapa peneliti juga mendukung adanya interaksi genotip $\mathrm{x}$ lingkungan (lokasi). Kuchanur et al. (2015) pada pengujian stress air pada jagung 
hibrida, Badu-Apraku et al. (2013) pada pengujian hibrida jagung 3- era pengembangan di 13 lokasi Afrika Barat, (Chimonyo et al., 2014) pada pengujian jagung bersari bebas pada berbagai lokasi di Afrika Selatan, Ndhlela et al. (2014) pada pengujian hibrida jagung toleran kekeringan pada 7 lokasi Zimbabwe menyimpulkan peran penting interaksi $\mathrm{G} \times \mathrm{E}$ terhadap daya hasil. Interaksi genotip dengan lingkungan telah dilaporkan terdapat pada sebelas field corn yang diuji multilokasi pada delapan lingkungan di Indonesia (Ruswandi et al., 2008). Walaupun interaksi genotip dengan lingkungan menyebabkan tidak konsistennya hasil pada setiap lingkungan, namun pada kondisi tertentu tanaman memiliki kemampuan untuk meminimalkan pengaruh lingkungan yang tidak menguntungkan, sekaligus memaksimalkan pengaruh lingkungan yang menguntungkan. Interaksi $G \times E$ yang nyata berhasil didemonstrasikan pada hasil dan karakter yang berasosiasi dengan hasil kedelai yang dibudidayakan pada lingkungan ternaungi (Sundari et al., 2016). Mereka mengidentifikasi genotip kedelai yang adaptif terhadap lingkungan ternaungi.

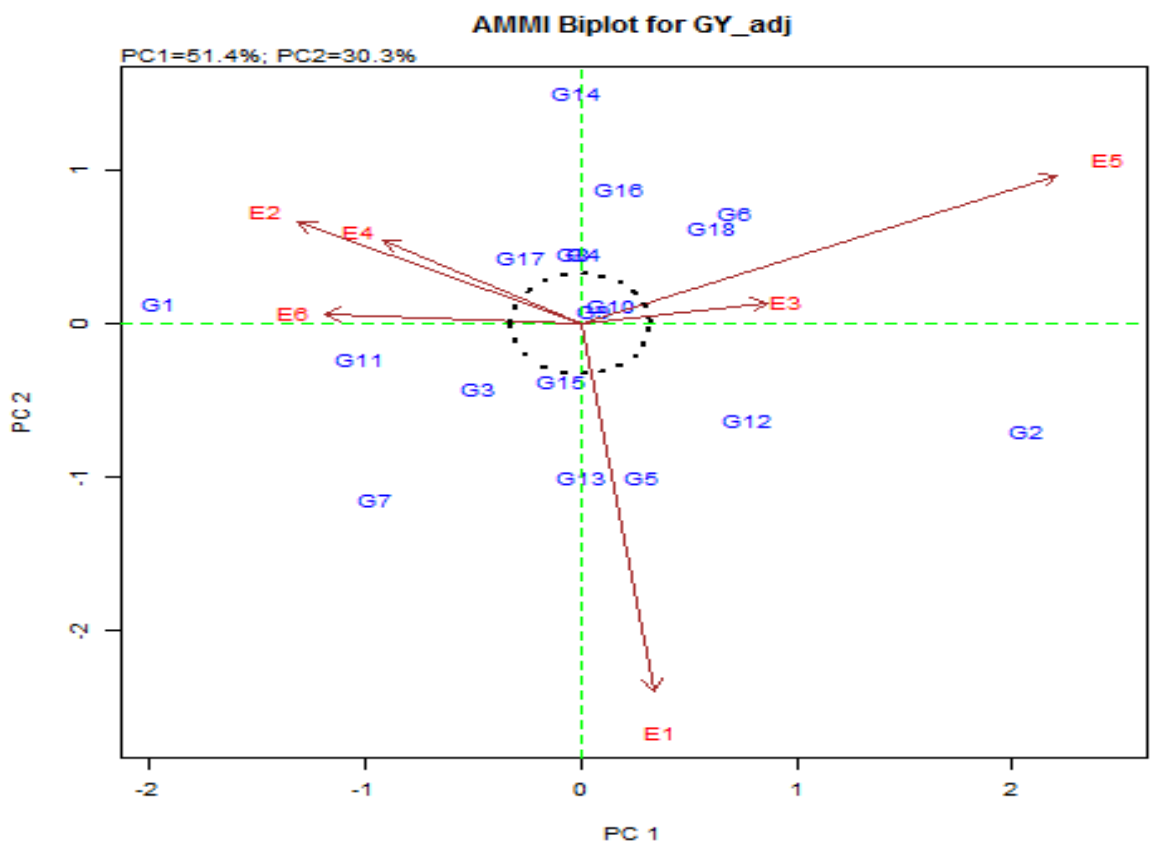

Gambar 1. Biplot AMMI-2 untuk karakter daya hasil. G1 (BS= Bisi sweet), G2 (SB= Sweet Boy), Padjadjaran G3 (15 x 17), Padjadjaran G4 (22 x 17), Padjadjaran G5 (24 x 17), Padjadjaran G6 (25 x 17), Padjadjaran G7 (26 x 17), Padjadjaran G8 (30 x 17), Padjadjaran G9 (31 x 17), Padjadjaran G10 ( $32 \times 17)$, Padjadjaran G11 (33 x 17), Padjadjaran G12 (4 x 17), Padjadjaran G13 (41 x 17), Padjadjaran G14 (43 x 17), Padjadjaran G15 (46 x 17), Padjadjaran G16 (47 x 17), Padjadjaran G17 (52 x 17), dan Padjadjaran G18 (9 × 17); E1 (Jatinangor musim 1), E2 (Jatinangor musim 2), E3 (Lembang musim 1), E4 (Lembang musim 2), E5 (Wanayasa musim 1) dan E6 (Wanayasa musim 2).

Interaksi G x E pada pengujian multilokasi memberikan informasi stabilitas dan adaptabilitas suatu genotip yang diuji. Analisis AMMI pada karakter daya hasil yang dievaluasi pada enam lingkungan pengujian memperlihatkan bahwa $5,26 \%$ dari total jumlah kuadrat merupakan kontribusi dari faktor genotip, $42,98 \%$ dari total jumlah 
kuadrat merupakan pengaruh lingkungan (lokasi dan musim) dan 22,12\% disebabkan oleh interaksi genotip x lingkungan. Hal ini mengindikasikan bahwa genotip yang memiliki latar belakang genetik berbeda dan ditanam pada lokasi yang berbeda akan memperlihatkan hasil yang berbeda karena interaksi genotip $\mathrm{x}$ lingkungan (lokasi dan musim) memberikan kontribusi cukup besar terhadap variasi karakter hasil (Gambar 1).

Pengaruh utama IPCA 1 terhadap interaksi $G \times$ E tersaji pada Gambar 1 dan Tabel 2. Interaksi bilinier pertama dari analisis AMMI dianalisis berdasarkan interaksi $G \times E$, dihitung dari jumlah kuadrat interaksi genotip $x$ lingkungan (lokasi) dengan nilai bilinier pertama (IPCA-1) sebesar $51,40 \%, 30,30 \%$ oleh komponen
IPCA-2, dan $10,50 \%$ oleh IPCA-3. Berdasarkan Tabel 2, model AMMI yang berlaku untuk membentuk biplot AMMI adalah AMMI-2. Nilai IPCA (Interaction Principal Component Axis) pengaruh hibrida pada analisis AMMI mengindikasikan kestabilan hibrida pada lingkungan (lokasi) tertentu. Hibrida yang memiliki skor IPCA mendekati nilai nol diasumsikan hibrida yang memiliki kontribusi yang kecil dari interaksi, maka hibrida tersebutlah yang stabil pada semua lingkungan (lokasi) yang diujikan. Berdasarkan AMMI biplot (Gambar 1) hibrida jagung manis berdaya hasil yang stabil di semua lokasi pada dua musim tanam diperlihatkan oleh hibrida G5 (SR 24 x SR 17) dan G 10 (SR 32 x SR 17).

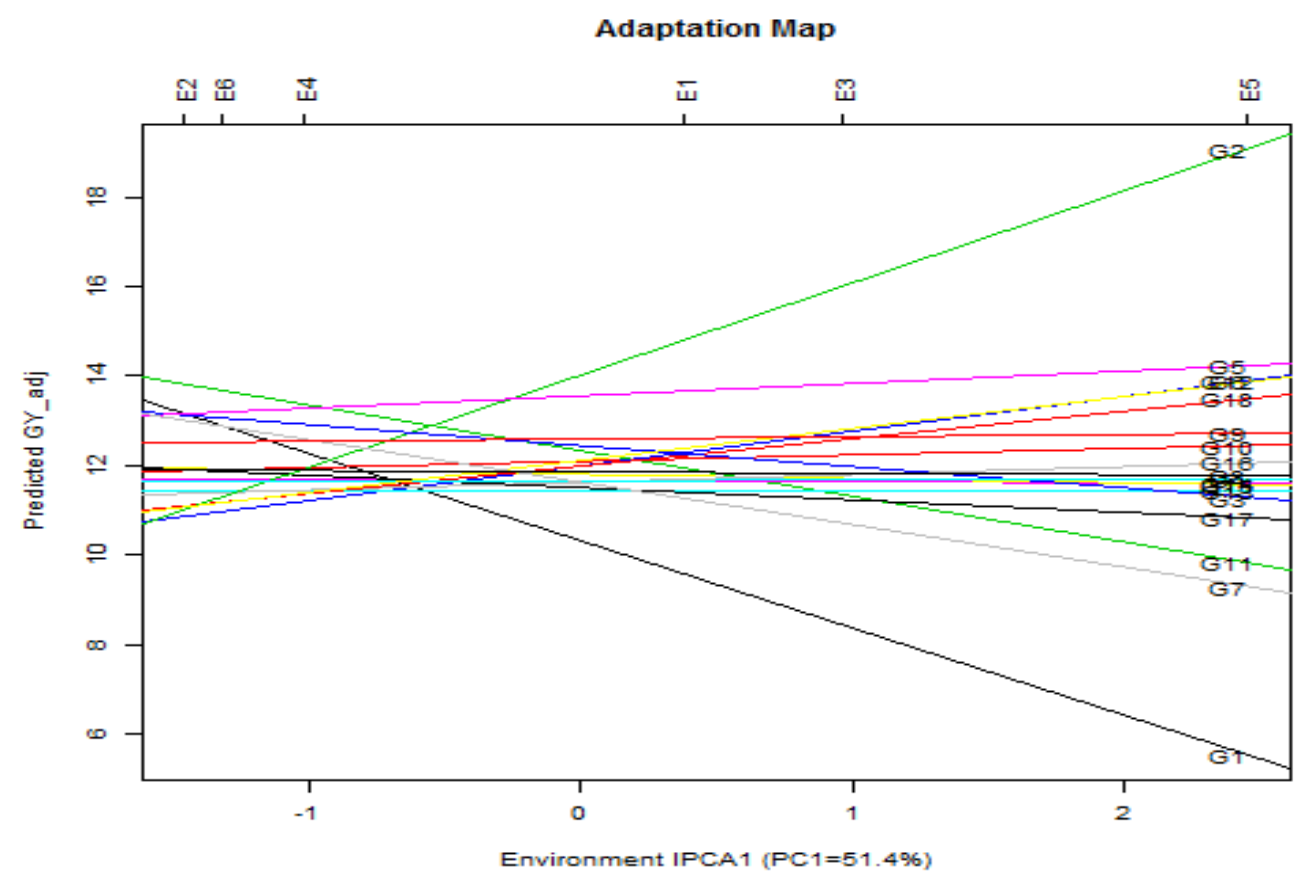

Gambar 2. Peta adaptasi daya hasil hibrida jagung manis Padjadjaran di Jawa Barat. G1 (BS= Bisi sweet), G2 (SB= Sweet Boy), Padjadjaran G3 (15 x 17), Padjadjaran G4 (22 x 17), Padjadjaran G5 (24 x 17), Padjadjaran G6 (25 x 17), Padjadjaran G7 (26 x 17), Padjadjaran G8 (30 x 17), Padjadjaran G9 (31 x 17), Padjadjaran G10 (32 x 17), Padjadjaran G11 (33 x 17), Padjadjaran G12 (4 x 17), Padjadjaran G13 (41 x 17), Padjadjaran G14 (43 x 17), Padjadjaran G15 (46 x 17), Padjadjaran G16 (47 x 17), Padjadjaran G17 (52 x 17), dan Padjadjaran G18 (9 17 ); E1 (Jatinangor musim 1), E2 (Jatinangor musim 2), E3 (Lembang musim 1), E4 (Lembang musim 2), E5 (Wanayasa musim 1) dan E6 (Wanayasa musim 2) 
Adaptasi hibrida jagung manis tersaji pada Gambar 2, sedangkan daya hasil hibrida jagung manis pada beberapa lokasi selama 2 tahun berturut- turut disajikan pada Tabel 3. Hibrida G 2 (Sweet boy) merupakan hibrida jagung manis yang beradaptasi baik pada lokasi Jatinangor (E1), Lembang (E3) dan Wanayasa (E5) pada musim pertama, sebaliknya hibrida Padjadjaran G 5 (SR 24 x SR 17) merupakan hibrida jagung manis yang beradaptasi baik pada lokasi Jatinangor (E2), Lembang (E4) dan Wanayasa (E6). Hibrida jagung manis Padjadjaran G 11 (SR 33 x SR 17) merupakan hibrida yang memiliki daya hasil tertinggi dan beradaptasi baik pada lokasi Jatinangor (E2) dan Wanayasa (E6). Para petani biasanya tertarik pada kultivar yang mampu memberikan penampilan yang konsisten. Oleh karena itu, hibrida jagung manis Padjadjaran $\mathrm{G} 10$ yang memiliki penampilan hasil yang stabil di ketiga lokasi pada dua musim tanam dapat dipertimbangkan untuk dilepas sebagai kultivar unggul jagung manis di Jawa Barat. Hibrida jagung manis Padjadjaran G 5 dan Padjadjaran G 11 yang berpenampilan hasil yang baik pada lokasi dan musim tertentu dapat dipertimbangkan untuk dilepas sebagai kultivar unggul yang lokasi spesifik di Jawa Barat.

Tabel 3. Hasil jagung manis pada beberapa lingkungan pengujian

\begin{tabular}{|c|c|c|c|c|c|c|c|c|c|c|}
\hline \multirow{2}{*}{ No } & \multirow{2}{*}{\multicolumn{4}{|c|}{ Genotipe }} & \multicolumn{6}{|c|}{ Hasil (ton / ha) } \\
\hline & & & & & E1 & E2 & E3 & E4 & E5 & E6 \\
\hline 1 & G1 & BS & $x$ & SR 17 & 9,96 & 14,46 & 10,75 & 6,87 & 7,91 & 11,91 \\
\hline 2 & G2 & SB & $x$ & SR 17 & 17,56 & 11,86 & 17,75 & 6,33 & 20,73 & 9,81 \\
\hline 3 & G3 & SR15 & $x$ & SR 17 & 14,79 & 13,37 & 11,62 & 9,86 & 14,10 & 10,87 \\
\hline 4 & G4 & SR22 & $x$ & SR 17 & 11,66 & 12,59 & 11,71 & 7,94 & 15,47 & 10,52 \\
\hline 5 & G5 & SR24 & $x$ & SR 17 & 17,71 & 14,01 & 13,52 & 8,23 & 16,53 & 11,33 \\
\hline 6 & G6 & SR25 & $x$ & SR 17 & 11,45 & 12,28 & 14,60 & 8,26 & 17,00 & 9,13 \\
\hline 7 & G7 & SR26 & $x$ & SR 17 & 15,15 & 12,86 & 13,35 & 8,44 & 9,76 & 10,22 \\
\hline 8 & G8 & SR3O & $x$ & SR 17 & 11,66 & 12,19 & 12,42 & 8,54 & 15,31 & 11,08 \\
\hline 9 & G9 & SR31 & $x$ & SR 17 & 13,51 & 13,63 & 13,99 & 8,98 & 15,32 & 10,08 \\
\hline 10 & G10 & SR32 & $x$ & SR 17 & 12,87 & 11,38 & 12,28 & 8,77 & 15,80 & 11,42 \\
\hline 11 & G11 & SR33 & $x$ & SR 17 & 13,72 & 14,85 & 12,21 & 9,10 & 12,39 & 11,76 \\
\hline 12 & G12 & SR4 & $x$ & SR 17 & 14,72 & 10,60 & 14,69 & 6,90 & 15,43 & 9,61 \\
\hline 13 & G13 & SR41 & $x$ & SR 17 & 14,86 & 11,71 & 13,48 & 5,51 & 12,66 & 10,42 \\
\hline 14 & G14 & SR43 & $x$ & SR 17 & 8,53 & 14,96 & 14,40 & 6,96 & 15,34 & 9,80 \\
\hline 15 & G15 & SR46 & $x$ & SR 17 & 13,80 & 13,05 & 12,80 & 6,55 & 13,97 & 10,64 \\
\hline 16 & G16 & SR47 & $x$ & SR 17 & 10,67 & 13,21 & 12,41 & 8,31 & 15,96 & 9,23 \\
\hline 17 & G17 & SR52 & $x$ & SR 17 & 11,09 & 11,78 & 12,36 & 8,27 & 14,06 & 11,47 \\
\hline 18 & G18 & SR9 & $x$ & SR 17 & 11,31 & 12,29 & 15,43 & 7,52 & 16,04 & 9,38 \\
\hline
\end{tabular}

\section{SIMPULAN}

1. Interaksi $G \times E$ menentukan penampilan daya hasil hibrida jagung manis Padjadjaran.

2. Hibrida jagung manis Padjadjaran G 10 memiliki penampilan hasil yang stabil di ketiga lokasi pada dua musim tanam.

3. Hibrida Padjadjaran G 5 merupakan hibrida jagung manis yang spesifik musim kedua di ketiga lokasi, sedangkan Hibrida
Padjadjaran G 11 merupakan hibrida jagung manis yang memiliki daya hasil tertinggi dan beradaptasi baik pada lokasi Jatinangor dan Wanayasa di musim kedua.

\section{UCAPAN TERIMAKASIH}

Tim peneliti menyampaikan ucapan terima kasih pada Universitas Padjadjaran dan Kementrian Pendidikan Tinggi dan Riset 
Teknologi Republik Indonesia yang telah membiayai penelitian ini melalui skema Hibah Kompetensi yang diberikan pada Dedi Ruswandi.

\section{DAFTAR PUSTAKA}

Akter, A., Jamil Hasan, M., Kulsum,M.U., Rahman, M.H., Paul, A. K. , Lipi, L.F., \& Akter, S. (2015). Genotype X environment interaction and yield stability analysis in hybrid rice (Oryza sativa L.) by AMMI biplot. Bangladesh Rice Journal, 19(2), 83-90. https://doi.org/https://doi.org/10.332 9/brj.v19i2.28168

Aruna, C., Rakshit, S., Shrotria, P. K., Pahuja, S. K., Jain, S. K., \& Kumar, S. S. (2015). Assessing genotype-by-environment interactions and trait associations in forage sorghum using GGE biplot analysis. Journal of Agricultural Science, 154(1), 73(1), 73-86. https://doi.org/10.1017/S0021859615 000106

B. Badu-Apraku, R.O. Akinwale, J. Franco, and M. O. (2012). Assessment of Reliability of Secondary Traits in Selecting for Improved Grain Yield in Drought and Low-Nitrogen Environments. Crop Science, 52(October), 2050-2062. https://doi.org/10.2135/cropsci2011.1 2.0629

Badu-Apraku, M.A.B. Fakorede, A.O. Talabi, M. Oyekunle, I. . A., \& R.O. Akinwale, B. Annor, G. Melaku, Y. Fasanmade, and M. A. (2016). Gene Action and Heterotic Groups of Early White Quality Protein Maize Inbreds under Multiple Stress Environments. Crop Science, 199(february), 183-199. https://doi.org/10.2135/cropsci2015.0 5.0276
Badu-Apraku, B., Fakorede, M. A. B., Oyekunle, M., Yallou, G. C., ObengAntwi, K., Haruna, A., ... Akinwale, R. O. (2015). Gains in Grain Yield of Early Maize Cultivars Developed During Three Breeding Eras under Multiple Environments. Crop Science, 55(Maret), 527-539. https://doi.org/https://doi.org/10.213 5/cropsci2013.11.0783

Badu-Apraku, B., Oyekunle, M., Menkir, A., Obeng-Antwi, K., Yallou, C. G., Usman, I. S., \& Alidu, H. (2013). Comparative Performance of Early-maturing Maize Cultivars Developed in Three Eras under Drought Stress and Wellwatered Environments in West Africa. Crop Science, 53(1), 1298-1311. https://doi.org/10.2135/cropsci2012.1 1.0640

Balestre, M., Souza, J. C. De, Pinho, R. G. Von, Oliveira, R. L. De, Mauro, J., \& Paes, V. (2009). Yield stability and adaptability of maize hybrids based on GGE biplot analysis characteristics, 219-228.

Brown, J. \& Caligari, P. (2008). An Introduction to Plant Breeding (1st ed.). Blackwell Publishing Ltd.Oxford, England.

Castillo, D., Madariaga, R., \& Mellado, M. (2012). ADAPTABILITY AND GENOTYPE $\times$ ENVIRONMENT INTERACTION OF, 72(June), 167-174. Retrieved from http://dspace.utalca.cl/bitstream/195 0/9092/1/Texto Completo.pdf

Chimonyo, V. G. P., Mutengwa, C. S., \& Chiduza, C. (2014). Genotype $\times$ environment interactions and yield stability of stress-tolerant openpollinated maize varieties in the Eastern Cape province, South Africa. South African Journal of Plant and Soil, 31(2), 61-68. https://doi.org/10.1080/02571862.20 14.868048 
Fan, X.M., Kang, M.S., Chen, H., Zhang, Y., Tan, J., \& Xu, C. (2007). Yield stability of maize hybrids evaluated in multienvironment trials in Yunnan, China. Agronomy Journal 99: 220-228. https://doi.org/10.2134/agronj2006.0 144

Flores, F., Hybl, M., Knudsen, J.C., Marget, P., Muel, F., Nadal, S., Narits, L., Raffiot, B., Sass, O., Solis, I., Winkler, J., Stoddard, F. L., \& Rubiales, D. (2013). Adaptation of spring faba bean types across European climates. Field Crops Research, 145, 1-9, 145, 1-9. Retrieved from

https://www.sciencedirect.com/scienc e/article/abs/pii/S0378429013000403

Gauch, Jr., H.G. \& Zobel, R. W. (1996). AMMI analysis of yield trial. In M.S. Kang and H.G. Gauch, Jr (Eds). Genotype-byenvironment Interaction. , Boca Raton. New York, United State of America.: CRC Press.

Gomez, K.A., \& Gomez, A. A. (1995). Prosedur Statistik untuk Penelitian Pertanian (2nd ed.). Jakarta: UI-Press.

Hoyos-Villegas, V., Wright, E.M., \& Kelly, J. D. (2016). GGE biplot analysis of yield association with root traits in a Mesoamerican bean diversity panel. Crop Science, 56, 1081-1094. Retrieved from

https://acsess.onlinelibrary.wiley.com /doi/full/10.2135/cropsci2015.10.0609

IRRI. (2014a). International Rice Research Institute. (2014a). Plant Breeding Tools. User's Manual. Biometrics and Breeding Informatics. Plant Breeding, Genetics and Biotechnology Division. Plant Breeding, Genetics and Biotechnology Division.

IRRI. (2014b). Statistics for Agriculture Research. User's Manual. Biometrics and Breeding Informatics. Plant
Breeding, Genetics and Biotechnology Division.

Kuchanur, P. H., Salimath, P. M., Wali, M. C., \& Hiremath, C. (2015). GGE biplot analysis for grain yield of single cross maize hybrids under stress and nonstress conditions. Indian Journal of Genetics, 75(4), 514-517. https://doi.org/10.5958/09756906.2015.00082.6

Ndhlela,T., Herselman, L., Magorokosho, C., Setimela, P., Mutimaamba, C. (2014). Genotype $x$ environment interaction of maize grain yield using AMMI biplots. Crop Science, 54, 1992-1999. https://doi.org/doi: $\quad$ 10.2135/ cropsci2013.07.0448

Oliveira, E. J. De, Paulo, J., Freitas, X. De, \& Jesus, O. N. De. (2014). AMMI analysis of the adaptability and yield stability of yellow passion fruit varieties. Science Agriculture, 71(2), 139-145. https://doi.org/https://doi.org/10.159 o/S0103-90162014000200008

Rak, K., Navarro, F. M., \& Palta, J. P. (2013). Genotype $x$ storage environment interaction and stability of potato chip color: Implications in breeding for cold storage. Crop Science, 53, 1944-1952. https://doi.org/https://doi.org/10.213 5/cropsci2013.02.0089

Ruswandi, D., Hastini, T., Suhada, A., Istifadah, N., Ismail, A., \& Ruswandi, S. (2008). Stabilitas dan adaptabilitas hasil di delapan lokasi. Zuriat, 19(1), 71-85.

Ruswandi, D., Supriatna, J., Rostini, N., \& Suryadi, E. (2016). Research Article Assessment of Sweetcorn Hybrids Under Sweetcorn / Chilli Pepper Intercropping in West Java, Indonesia. Journal of Agronomy, 15(3), 94-103. https://doi.org/10.3923/ja.2016.94.10 3 
Sundari, T., Nugrahaeni, N., \& Anggoro, W. (2016). Interaksi Genotipe $x$ Lingkungan dan Stabilitas Hasil Biji Kedelai Toleran Naungan Genotype $x$ Environment Interaction and Stability of Grain Yield of Shade Tolerant Soybean. Jurnal Agronomy Indonesia, 44(1), 16-25. Retrieved from http://103.10.105.65/index.php/jurnal agronomi/article/view/12487

Temesgen, T., Keneni, G., Sefera, T., \& Jarso, M. (2015). Yield stability and relationships among stability parameters in faba bean ( Vicia faba L .) genotypes. The Crop Journal, 3, 258-
268.

https://doi.org/https://doi.org/10.101 6/j.cj.2015.03.004

van der Merwe, R., Labuschagne, M.T., Herselman, L., \& Hugo, A. (2013). Stability of seed oil quality traits in high and mid-oleic acid sunflower hybrids. Euphytica, 193, 157-168. https://doi.org/https://doi.org/10.100 7/s10681-013-0888-0 